\title{
LARVAL REARING AND SPAT PRODUCTION OF GREEN MUSSEL Mytilus viridis LINNAEUS IN FRENCH POLYNESIA
}

\author{
AQUACOP ${ }^{1}$ \\ Centre Océanologique du Pacifique \\ CNEXO-COP \\ B.P. 7004 \\ Taravao, Tahiti (French Polynesia)
}

\section{ABSTRACT}

To develop mussel culture in the South Pacific and especially in French Polynesia, trials for producing spat of Mytilus viridis were conducted at the Centre Océanologique du Pacifique (COP) of the Centre National pour 1'Exploitation des Océans (CNEXO) in Tahiti.

Spawning is attained through thermal stimulation. Larval rearing is conducted in 800-liter cylindroconical tanks. Every two days the water is changed and antibiotics are added as a preventive treatment.

Monochrysis lutheri and an Isochrysis locally isolated are used as food. Metamorphosis and settlement are achieved between the 10th and 17th days. A $15 \mathrm{~m}^{3}$ tank supplied with flowing water from a shrimp rearing pond is used for the pre-growth. The marketable spat size (7-8 $\mathrm{mm}$, $40 \mathrm{mg}$ ) is reached in one month after settlement. The survival rate between D stage and marketable spat size is 10 s and 2 million spat were produced. The actual hatchery, with six 800-liter tanks, should give 2 to $3.10^{6}$ spat/month.

\section{INTRODUCTION}

In order to develop shellfish culture in the South Pacific Islands, an experimental shellfish hatchery has been created by the Centre océanologique du Pacifique (COP) in Tahiti. From 1975 until 1977, this hatchery worked with the Japanese oyster (Crassostrea gigas) and a technique

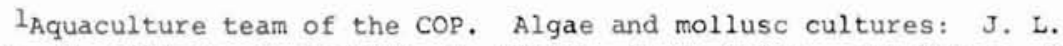
Martin, O. Millous, Y. Normant, D. Gillet, O. Le Moine. Nutrition: A. Febvre, P. Vilmorin, J. J. Lainé, L. Mu, J. M. Guesne. Water quality control and treatment: J. Calvas, B. Couteaux, J. Bonfils, J. Y. Robert. Pathology: J. F. Le Bitoux, S. Robert. Crustacean and fish cultures: P. J. Hatt, M. Jarillo, J. P. Landret, J. Goguenheim, F. Fallourd, 0. Avalle, J. Moriceau, D. Lacroix, S. Brouillet, R. Galzin, H. Pont, D. Amaru, V. Vanaa, A. Bennett, D. Sanford. Technology: J. F. Virmaux. Aquaculture program coordinator in tropical area: A. Michel. 
for larval rearing and spat production was developed (Aquacop, 1977). This technique, derived from those described by Loosanoff and Davis (1963) and Walne (1966), has been adapted to the tropical conditions.

Since February 1978, studies have been conducted with a tropical species, the green mussel (Mytilus viridis L.). Spawning and larval development of $M$. viridis have already been described by Tan (1975), Virabhadra Rao et al. (1976) and Sivalingam (1977). These authors obtained eggs and veliger larvae in the laboratory but the larval survival rate was very low. This paper reports the results of four experimental mass rearings which have produced 2 million marketable spat-size mussels.

\section{MATERIAL AND METHODS}

The hatchery has an area of $40 \mathrm{~m}^{2}$, covered by a semi-transparent fiberglass roof, with walls made of opaque plastic sheets. Six fiberglass rearing tanks of 800 -liter capacity are used. They have a conical bottom (slope $45^{\circ}$ ) and include a double wall where the lagoon water is circulated if necessary to avoid temperature variations. Aeration is supplied by an airstone at the center of the conical bottom. Seawater, pumped into the lagoon from $6 \mathrm{~m}$ depth, has oceanic characteristics with a low level of organic and inorganic matter. Temperature range is 25.5 to $29^{\circ} \mathrm{C}$. Salinity fluctuates around $35 \mathrm{ppt}$ and $\mathrm{pH}$ is 8.2 . In the hatchery, the water is filtered at 5 and $0.5 \mu$. In the rearing tanks, temperature varies between 26.5 and $28^{\circ} \mathrm{C}$ and diurnal variation is $1^{\circ} \mathrm{C}$.

The first spawning occurred from a brood stock of 15 animals imported from the Philippines. All subsequent spawnings were obtained from reared brood stock.

Spawning is induced by thermal stimulation from $21-33^{\circ} \mathrm{C}$. Only one temperature jump is necessary. Eggs and sperm are recovered separately and filtered on an $85 \mu$ nylon mesh to remove remains. Fertilization is effected by mixing spermatozoildes and eggs in a proportion of about 10 spermatozoides per egg. This ratio is controlled by microscopic observation. The fertilized eggs are put in a 800-1iter tank. After 24 hours, D stage larvae are recovered and distributed in the rearing tanks at a density of 3,000-5,000 larvae/liter.

The water is changed every two days. Concentrators made of PVC tubes (250 mm dia) are used to collect the larvae; these are fitted with different meshes: $48 \mu$ (days 2 and 4), $65 \mu$ (day 6), $85 \mu$ (day 8), $100 \mu$ (day 10 until metamorphosis). The tanks are cleaned with fresh water and detergent. The larvae are collected in a 10-1iter bucket and two one-ml samples are made up for the numbering and measurement. At metamorphosis, the water is renewed every day without draining the tank.

Food is a mixture of Isochrysis sp. and Monochrysis lutheri. The initial density in rearing tanks is 25,000 cells/ml of each species. The algae are added every two days after the water change. During metamorphosis, 12,500 cells/ml of Isochrysis sp., 12,500 cells/ml of $M$. lutheri and $50,000 \mathrm{cells} / \mathrm{ml}$ of Skeletonema costatum are added every day. At the end of the settlement period, s. costatum only is used ad libitum. Algae are produced in two constant temperature culture rooms, one at $20^{\circ} \mathrm{C}$ for $M$. Iutheri and $S$. costatum and the other at $25^{\circ} \mathrm{C}$ for Isochrysis sp. which has been locally isolated (Aquacop, 1977). 
Larval rearings are treated every two days with a sulfamide, $14 \mathrm{mg} /$ liter of Sulfadimerazine. During rearing 4 , two tanks were not treated, two were treated with $7 \mathrm{mg} /$ liter and two with $14 \mathrm{mg} / \mathrm{liter}$. The six tanks were at the same conditions of larval density, food and temperature. The larvae were from the same spawning.

For the settlement, two techniques have been tried with or without collectors. In the first technique, nylon nets as collectors were suspended in the larval tanks. In the second technique, eyed larvae were transferred in the pre-growth tank and settled on bottom and walls of the tank.

For the pre-growth, a $15 \mathrm{~m}^{3}$ tank is supplied with flowing water from a growing Penaeid pond where phytoplankton density is high. During three weeks, this tank is not emptied as the young spat do not tolerate exposure to air. The spat are recovered after one month and the total number is estimated by weight. Spat growth is followed by the total length and by weight when the length is over $6 \mathrm{~mm}$.

\section{RESULTS}

\section{MATURATION, SPAWNING AND FERTILIZATION}

Maturation is obtained on brood stock fed different algal diets: 1) natural phytoplankton with predominance of diatoms; 2) phytoplankton of shrimp pond with predominance of Dinoflagellate and Chlorella; and 3) Skeletonema costatum cultivated in the algae culture room.

Seawater temperature in Tahiti permits maturation and spawning year-round without particular conditioning period and we obtained spawning in warm $\left(29^{\circ} \mathrm{C}\right)$ or cold $\left(25.5^{\circ} \mathrm{C}\right)$ seasons. Mussels spawn one hour after thermal stimulation, with males spawning first. The brood stock being young ( 6 months to one year), males are more numerous (708) than females (308). The percentage of fertilization is about 908 . The first polar body is extruded $10 \mathrm{~min}$ after fertilization. The trocophore stage is reached in 8 hours and D stage larvae in 24 hours.

LARVAL REARING AND SETTLEMENT

For the first 10 days, larval density may be high, survival and growth are the same for the two densities tested $(3,000$ or 5,000 larvae) liter). After the 10th day, the density must be decreased to 2,000 larvae/liter. In the tanks, where density was higher, a delay in metamorphosis and settlement has been observed.

After the 8th day, algae control counts show that, for the high density larval tank, it is necessary to supply algae each day. After the beginning of metamorphosis, the use of $S$. costatum favors growth of the young spat.

Sulfadimerazine used for the bacterial control gives good results: in experiment 4 , the survival rate at day 10 was $26.5 \%$ for the two untreated tanks, 708 for the two treated with $7 \mathrm{mg} / \mathrm{liter}$, and 758 for the two treated with $14 \mathrm{mg} / 1$ iter (Table 1). In these conditions, larval growth is strong and regular (Table 2, Fig. 1). The pediveliger stage is reached at the 15 th day and the size is about $260 \mathrm{H}$. 
TABLE 1. Survival Rate at Day 10 with Different Sulfadimerazine Concentrations

$\begin{array}{cc}\text { Sulfadimerazine } & \text { Survival rate } \\ \text { (mg } 1^{-1} \text { ) } & \text { at day } 10 \\ 0 & 26.58 \\ 7 & 70.08 \\ 14 & 75.08\end{array}$

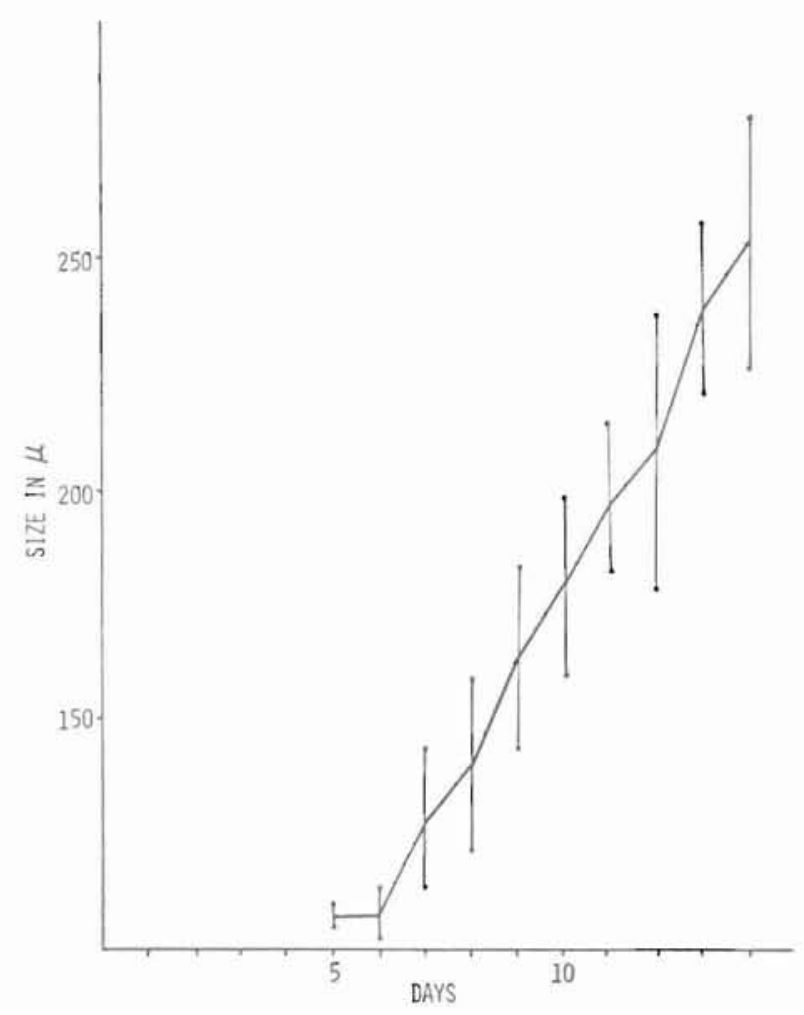

Figure 1. Larval growth curve. The vertical lines give the 958 confidence interval.

The survival rate may be easily estimated until the 10 th day by counting the larvae in a one-milliliter sample. It exceeds 708 after the $100 \mu$ screening. The estimate of the survival rate at the pediveliger stage is difficult because the larvae agglutinate and the sampling is not right.

The use of nylon net as collectors (experiment 2) seems to agree with settlement, for very few larvae are found settled on the tank walls; on the other hand, the settlement of the pediveliger larvae in the pregrowth tank (experiments 3 and 4) involves a perceptible loss. 
TABLE 2. Growth (in microns) of the Larvae During Four Rearings and Mean Size at Each Day (with 958 confidence interval)

\begin{tabular}{|c|c|c|c|c|c|c|c|c|c|c|c|c|c|c|c|}
\hline \multirow{2}{*}{ Day } & \multicolumn{14}{|c|}{ Size in microns } & \multirow[b]{2}{*}{ Mean } \\
\hline & \multicolumn{2}{|c|}{ Exp 1} & & & \multicolumn{3}{|l|}{ Exp 2} & \multirow[t]{2}{*}{ Exp 3} & \multicolumn{6}{|c|}{ Exp 4} & \\
\hline \multirow{2}{*}{\multicolumn{16}{|c|}{$\begin{array}{l}1 \\
2\end{array}$}} \\
\hline & & & & & & & & & & & & & & & \\
\hline \multicolumn{16}{|l|}{3} \\
\hline 4 & & & & & & & & & & & & & & & \\
\hline 5 & - & - & 109.0 & 106.3 & - & 107.9 & - & 104.9 & - & - & - & - & - & - & $107.0=2.9$ \\
\hline 6 & 108.0 & 103.7 & - & - & 103.9 & - & 116.2 & - & - & 107.0 & - & - & - & - & $107.8 \pm 6.2$ \\
\hline 7 & - & - & 158.0 & 145.3 & - & 145.7 & - & 122.9 & 112.3 & - & 111.1 & 112.0 & - & 118.8 & $128.3 \pm 15.5$ \\
\hline 8 & 137.2 & 127.5 & - & - & 164.5 & - & 160.4 & - & - & 133.4 & - & - & 117.9 & - & $140.1 \pm 19.4$ \\
\hline 9 & - & - & 206.0 & 173.4 & - & 181.2 & - & 174.2 & 140.0 & - & 148.7 & 140.0 & - & 142.2 & $163.2=20.2$ \\
\hline 10 & 165.7 & 164.0 & - & - & 205.1 & - & 197.7 & - & - & 178.5 & - & - & 156,4 & - & $177.9 \pm 20.7$ \\
\hline 11 & - & - & - & 217.8 & - & 218.9 & - & 215.0 & 183.6 & - & 187.5 & 183.6 & - & 185.3 & $198.3 \pm 16.0$ \\
\hline 12 & 183.7 & 184.7 & - & - & 244.8 & - & 243.1 & - & - & 192.1 & - & - & 197.2 & - & $207.6 \pm 30.0$ \\
\hline 13 & - & - & - & 232.9 & - & 269.7 & - & 253.9 & - & - & 224.7 & 224.7 & - & 229.7 & $239.3 \pm 19.3$ \\
\hline 14 & - & - & - & - & 277.0 & - & 252.4 & - & - & 241.4 & - & - & 241.4 & - & $253.1 \pm 26.7$ \\
\hline 15 & & & & & & . & $\cdots$ & Settle & tent - & & & & & $\cdots$ & \\
\hline 16 & 256.0 & 255.2 & & & & & & & & & & & & & \\
\hline 17 & - & - & & & & & & & & & & & & & \\
\hline 18 & 299.0 & 289.2 & & & & & & & & & & & & & \\
\hline 19 & Sett1 & ement & & & & & & & & & & & & & \\
\hline
\end{tabular}


PRE-GROWTH

The pre-growth period lasts about one month, this being the time necessary to reach a 6-7 mm size. In experiment 1, during the first pregrowth week, the $15 \mathrm{~m}^{3}$ tank was drained for cleaning the bottom and the spat exposure to air involved a high mortality, the survival rate at the marketable size being only 4.78 (Table 3). For experiment 2, without tank draining, the survival rate was 11.28 (Table 3). During this period, the spat stay very mobile and go up the collectors, near the water surface. The relation between length and weight of the 6 to $10 \mathrm{~mm}$ spat are given in Table 4. Under our conditions, a $15 \mathrm{~m}^{3}$ tank, with a $500 \% /$ 24 hour water exchange rate can support the growth of $2.10^{6}$ spat until $7 \mathrm{~mm}$ size but only $1.10^{6}$ spat until $9 \mathrm{~mm}$ size.

TABLE 3. Evolution of the Survival Rate in Number of Larvae and Percent of the Initial Number of D Larvae

\begin{tabular}{|c|c|c|c|c|c|c|c|}
\hline \multirow[b]{2}{*}{ Stage } & \multirow{2}{*}{$\begin{array}{c}\text { Days } \\
\text { after } \\
\text { fertilization }\end{array}$} & \multicolumn{2}{|c|}{ Exp 1} & \multicolumn{2}{|c|}{ Exp 2} & \multicolumn{2}{|c|}{ Exp 3 and $4^{a}$} \\
\hline & & No. $\times 10^{6}$ & $\frac{\text { Survival }}{\text { Sul }}$ & No. $\times 10^{6}$ & Survival & No. $\times 10^{6}$ & Survival \\
\hline D larvae & 2 & 7.4 & 100.0 & 9.8 & 100.0 & 5.4 & 100.0 \\
\hline 180 H Larvae & $10-11$ & 6.7 & 90.5 & 7.4 & 75.5 & 3.9 & 72.2 \\
\hline Commercial spat & $45-50$ & 0.35 & 4.7 & 1.1 & 11.2 & 0.4 & 7.4 \\
\hline
\end{tabular}

anly tanks treated with 7 and $14 \mathrm{mg} 1^{-1}$ of Sulfadimerazine.

TABLE 4. Length-Weight Relation for the 6 to $10 \mathrm{~mm}$ Spat

\begin{tabular}{ccc}
\hline $\begin{array}{l}\text { Days after } \\
\text { fixation }\end{array}$ & Length (mm) & Weight (mg) \\
\hline \multirow{2}{*}{30} & 6 & 22 \\
& 7 & 33 \\
38 & 8 & 46.5 \\
45 & 9 & 68 \\
& 10 & 93 \\
\hline
\end{tabular}

\section{DISCUSSION}

In Tahiti, reared in natural temperature conditions, mussels appear to mature regularly if the phytoplankton is rich. They accept a varied phytoplankton and it is very easy to keep small brood stocks in the different Penaeid ponds of the COP where the shrimp excretion and distributed pellets ensure a natural enrichment which supports an important phytoplanktonic growth. Under these conditions, maturation and spawning are obtained throughout the year. The hatchery, developed for $C$. gigas larval rearing, is perfectly fitted for $M$. viridis. The material used in this hatchery is a standardized material which is useful in the crustacean COP hatcheries. 
The use of a locally isolated algae, Isochrysis sp., permits maintenance of living phytoplankton in the rearing tanks where the temperature average is $27.5^{\circ} \mathrm{C}$ and consequently better nutritive value ensues. The larval settlement on nylon net is easy to carry out and does not require special equipment. With six 800-1iter tanks, 20.10 $\mathrm{D}$ larvae can be bred and $2-3 \cdot 10^{6}$ marketable spat can be produced every month with a labor force of one technician.

It does not appear that the spat are damaged by transferral from the sanitary hatchery conditions to the pre-growth tank conditions where the water is not only rich in varied phytoplankton but also in bacterial population.

\section{CONCLUSION}

The larval molluso rearing technique in tropical areas, developed at the COP, has been used successfully for spat production of the green mussel, Mytilus viridis. It appears, henceforth, that spat production is reliable and in 1979, the hatchery will reach pilot scale.

In the first growing tests, mussele reached $15 \mathrm{~g}$ in seven months, without significent mortality, Predates, such as the polychaeta Polydora sp., which destroy the cysters, di not affect the mussels.

We conclude that Mytiluz viridis is a good species for tropical aquaculture and could be expanded in tho south tropical islands.

\section{LITERATURE CITED}

Aquacop. 1977. Elevage larvaire et production de naissain de Crassostrea gigas en milicu troplcel. Frcccedings 3rd Meeting, ICES Working Group on Mariculture. Actes de Colloque dil CNEXO 4:331-346,

Loosanoff, V. L., and H. C. Davis, 1963. Rearing of bivalve molluscs. Pages 1-136 in F. S. Russel (ed.), Advances in Marine Biology. Academic Press, London.

Sivalingam, P. M. 1977. Aquaculture of the green musse1, Mytilus viridis Linnaeus, in Malaysia. Aquacultur 11:97-312.

Tan, W. H. 1975. Egg and larval development in the green mussel, Mytilus viridis Linnaeus. The Veliger 18:151-155.

Virabhadra Rao, K., I. Krishna Kumari, and S. Z, Qasim. 1976. Aguaculture of green mussel Mytilus viridis L.; Spawning, fertilization and larval development. Indian Journal of Marine Science 5:113-116.

Walne, P. R. 1966. Experiments in the large-scale culture of the larvae of Ostrea edulis (L.). Fishery Investigations (London), Ser. 2, $25(4): 53 \mathrm{pp}$. 